\title{
Non-compliance among diabetic macular oedema patients on anti- vascular endothelial growth factor therapy in Malaysia
}

Wong Yew Meng, Chong Eve Lyn, Vanessa Yeo Yung Ling

Southern Specialist Eye Centre, Melaka, Malaysia

\section{Abstract}

Introduction: Diabetic macular oedema (DMO) is a major cause of visual loss in the diabetic population. There are several treatment options for DMO, including intravitreal anti-vascular endothelial growth factor (anti-VEGF) injections, which have been shown to improve visual outcomes. Good compliance to treatment regimens is associated with greater visual benefit.

Purpose: To estimate dropout rates and the associated reasons among DMO patients on three different anti-VEGF treatments.

Study design: A retrospective review of patients with DMO who were on bevacizumab, ranibizumab and aflibercept therapy from January 2014 to December 2016.

Materials and methods: Patients with DMO on anti-VEGF treatment in a private ophthalmology center were identified via an electronic database. Data on Malaysian residents aged 18 years or older were included. Foreign residents, the deceased, and those whose care had been transferred to another center were excluded from further analysis. Telephone interviews were then conducted with these patients based on a standard questionnaire to identify reasons for non-compliance.

Results: This study included 134 patients. The overall lost to follow-up rate was $56.0 \%$ (75/134). After excluding the deceased, those who opted for treatment at an alternative center, and uncontactable patients, 47 (35.1\%) were then identified as drop-outs. Financial constraint was the most common reason cited by $38.3 \%$ patients (18/47) and was highest in the bevacizumab group $(88.9 \%, 16 / 18)$. The second most common reason was lack of perceivable change in vision (25.5\%). In

Correspondence: Dr. Wong Yew Meng, FRCOphth, Southern Specialist Eye Centre, 309-310 Jalan Melaka Raya 1, Taman Melaka Raya 75000, Melaka, Malaysia.

E-mail: eyeservemalacca@gmail.com 
addition, $19.1 \%$ opted to stop treatment due to logistical difficulties and $12.8 \%$ of patients were satisfied with their stable visual acuity. Lastly, $4.3 \%$ were unable to continue with treatment due to poor general health.

Conclusion: The dropout rate of $35.1 \%$ is higher than in previous publications from other countries. This study clarifies the challenges face by some Malaysian patients in seeking treatment for what is often a chronic disease. These results have implications on designing ways to assist patients' cooperation with the standard of care.

Keywords: anti-VEGF therapy, diabetic macular oedema, dropout rate, intravitreal injections, Malaysia, patient compliance

\section{Abstrak}

Pengenalan: Edema makula diabetes (DMO) merupakan salah satu punca kemerosotan daya penglihatan dalam kalangan pesakit diabetes. DMO boleh dirawat dan suntikan faktor pertumbuhan endotel anti-vaskular intravitreal (anti-VEGF) merupakan salah satu cara perawatan DMO yang sudah terbukti keberkesanannya dalam usaha pemulihan daya penglihatan. Sesungguhnya, pematuhan rapi rejimen rawatan amat penting dan berkait rapat dengan usaha pemulihan daya penglihatan seseorang.

Objektif kajian: Menganggar kadar dan sebab-sebab pemberhentian rawatan dalam kalangan pesakit DMO bagi tiga cara perawatan anti-VEGF yang berbeza.

Reka bentuk kajian: Kajian retrospektif terhadap pesakit-pesakit DMO yang mendapatkan rawatan DMO melalui suntikan bevacizumab, ranibizumab, dan aflibercept dari Januari 2014 sehingga Disember 2016.

Instrumen dan kaedah kajian: Pesakit-pesakit DMO yang mendapatkan rawatan anti-VEGF di sebuah pusat rawatan oftalmologi swasta telah dikenal pasti melalui akses kepada pangkalan data elektronik yang sedia ada. Pesakit-pesakit yang telah dikenal pasti merangkumi warganegara Malaysia yang berumur 18 tahun dan ke atas. Warganegara asing, pesakit-pesakit yang telah meninggal dunia, dan pesakitpesakit yang telah dipindahkan ke pusat rawatan yang lain telah dikecualikan daripada kajian ini. Pesakit-pesakit yang telah dikenal pasti kemudiannya telah ditemu ramah berpaksikan soalan-soalan yang telah ditetapkan dalam kajian ini bagi memahami sebab-sebab permberhentian rawatan.

Hasil kajian: Bagi menjayakan kajian ini, seramai 134 pesakit telah dikenal pasti. Daripada 134 pesakit tersebut, 75 pesakit (56.0\%) telah dikenal pasti sebagai pesakit yang telah menghentikan rawatan. Setelah mengecualikan pesakit-pesakit yang telah meninggal dunia, pesakit-pesakit yang telah menukar pusat rawatan dan pesakit-pesakit yang gagal dihubungi, 47 pesakit (35.1\%) telah disahkan sebagai pesakit yang telah menghentikan segala rawatan. Masalah kewangan merupakan antara sebab utama bagi pemberhentian rawatan dengan kadar sebanyak 18 pesakit 
(38.3\%) dan masalah ini paling ketara dalam kalangan pesakit yang mendapatkan suntikan bevacizumab $(88.9 \%, 16 / 18)$. Antara sebab lain ialah kurang perubahan dalam daya penglihatan (25.5\%) dan kekangan logistik (19.1\%). Selain itu, sesetengah pesakit (12.8\%) telah menghentikan segala rawatan kerana berpuas hati dengan daya penglihatan yang sedia ada. Akhir sekali, sesetengah pesakit (4.3\%) telah menghentikan segala rawatan kerana masalah kesihatan.

Kesimpulan: Kadar pemberhentian rawatan sebanyak $35.1 \%$ yang telah direkodkan adalah lebih tinggi berbanding penerbitan negara-negara lain. Kajian ini menjelaskan kekangan yang dihadapi oleh warganegara Malaysia dalam usaha merawat penyakit kronik ini. Hasil kajian ini mempunyai implikasi dalam usaha menggalakkan kerjasama pesakit.

Kata kunci: anti-vaskular intravitreal, edema macula diabetes, kadar pemberhentian, suntikan intravitreal, Malaysia, pematuhan rejimen rawatan

\section{Introduction}

Diabetic macular oedema (DMO) is a major cause of visual loss in the diabetic population. ${ }^{1}$ The global prevalence of DMO is estimated to be about $7.48 \%$ among diabetic patients. ${ }^{2}$ In Southeast Asia, the prevalence has been estimated at $1.4-7.2 \% .{ }^{3}$ Especially in developing countries, patient education and awareness of diabetic eye diseases is still limited. ${ }^{4-6}$

Specifically in Malaysia, there has been an increase in the prevalence of diabetes among Malaysian adults, with the national prevalence estimated at $18.3 \%$ in 2019.7 The 2007 Diabetic Eye Registry reported the latest known national data on diabetic eye diseases, where $38.2 \%$ of diabetic Malaysians had some form of diabetic retinopathy, while an estimated $11.9 \%$ had evidence of diabetic maculopathy. ${ }^{8}$ The Malaysian National Eye Survey (NES II) in 2014 reported that diabetic retinopathy was the second most common cause of blindness. ${ }^{9}$

Current treatment options for DMO include intravitreal anti-vascular endothelial growth factor (anti-VEGF) injections, intravitreal steroid implants or injections, and laser photocoagulation. Anti-VEGF agents have been shown to improve visual outcomes. ${ }^{10}$ The types of anti-VEGF agents available for DMO treatment at the time of this study were bevacizumab (Avastin ${ }^{\oplus}$; Roche, Basel, Switzerland), ranibizumab (Accentrix ${ }^{\circledR}$; Alcon Novartis, Mumbai, India), and aflibercept (Eylea ${ }^{\circledR}$; Bayer, Berlin, Germany). It has also been shown that compliance to anti-VEGF agents is associated with an improvement in clinical outcome. ${ }^{11}$ It is therefore important to identify potential barriers that may hinder patients from achieving optimal visual recovery. The most cited reason for non-compliance to anti-VEGF therapy is lack of funding. ${ }^{11-}$ ${ }^{14}$ Other reasons include disease chronicity and lack of commitment in attending injection clinics, ${ }^{11}$ other illnesses, ${ }^{12}$ the psychological burden from the stress of 
receiving intravitreal injections, ${ }^{13}$ and decreasing baseline vision. ${ }^{14}$

The aim of this study is to evaluate reasons for patients dropping out of an anti-VEGF treatment regimen in a private ophthalmology center in Malacca, Malaysia. Identifying the causes of non-compliance will facilitate the formulation of appropriate patient-assistance strategies.

\section{Materials and methods}

All patients with DMO on anti-VEGF therapy from January 2014 to December 2016 at Southern Specialist Eye Centre (SSEC), a private eye center in Malaysia were identified from an electronic database. Institutional Review Board approval for the study was granted by the International Specialist Eye Centre (Reference No: 1/2020).

The socioeconomic factors affecting foreign residents may be significantly different and would require a separate study to investigate. Therefore, in order to reflect the local health care context, only Malaysian patients aged 18 years and older were included. Those who failed to attend review and/or treatment appointments for 6 months were identified as lost to follow-up (LTF) ${ }^{15}$. However, to determine the number of dropouts (i.e., those who should have been but were not under ongoing ophthalmic care), deceased patients, those whose care was transferred to another center or who were uncontactable, were excluded from further analysis.

A telephone interview was conducted with these patients based on a standard questionnaire to identify reasons for non-compliance. It was carried out by a single state registered nurse fluent in Malay, English, and Chinese. She was therefore able to conduct the interview in the patient's language of choice. Informed consent was obtained verbally at the start of the phone conversation. After a brief introduction to the study, the patient or a caretaker was asked an open-ended question

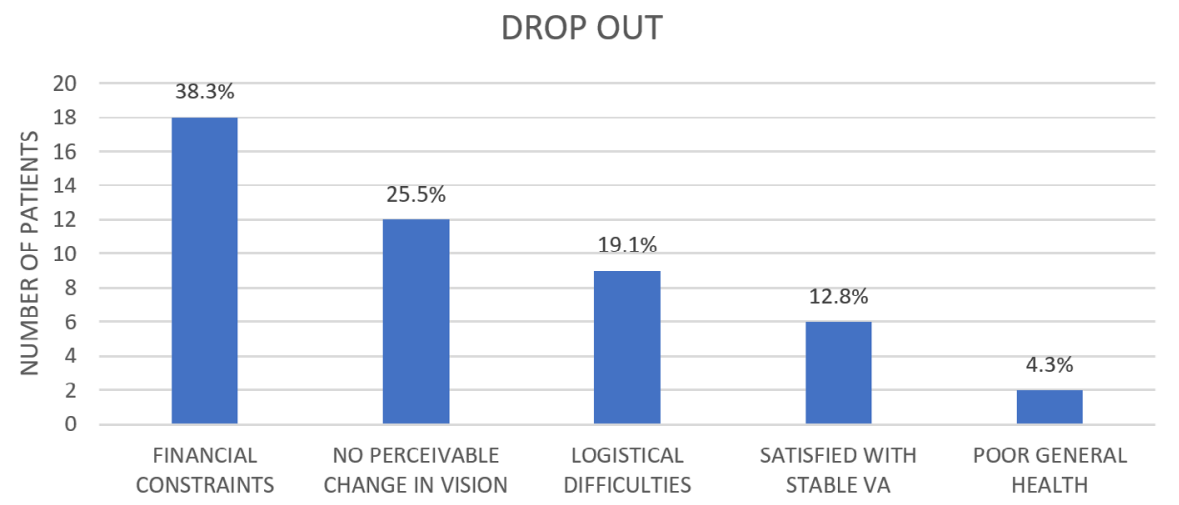

Fig. 1. Reasons for dropout. 
as to why they had stopped attending for treatment. Their responses were then classified under the following categories: financial constraints, poor general health, no perceivable change in vision, change of treatment center, logistical difficulties, satisfaction with stable or improved vision, or deceased.

The medical charts of these patients were reviewed to obtain data on gender, age, laterality, visual acuity, anti-VEGF agent, number of injections administered, and duration of treatment. Statistical analysis was performed using the one-way ANOVA and unpaired t-test where appropriate.

\section{Results}

From January 2014 to December 2016, there were 162 patients at SSEC who were identified as being on anti-VEGF therapy for DMO. One hundred thirty-four patients were Malaysians and included for analysis. Patient demographics are summarized in Tables 1 and 2.

A total of 75 patients (56.0\%) were found to have been LTF. Twelve of 75 patients $(16.0 \%)$ opted to continue treatment at an alternative center, where an eye center closer to home was a more convenient option. Eight patients (10.7\%) were reported deceased and a further eight (10.7\%) were uncontactable. These three groups were not considered for further analysis. The final result for the remaining $47(35.1 \%)$, the

Table 1. Patient demographics relative to gender

\begin{tabular}{|l|l|l|l|}
\hline Gender & $\begin{array}{l}\text { Number of patients who } \\
\text { continued treatment }\end{array}$ & $\begin{array}{l}\text { Number of patients } \\
\text { lost to follow-up }\end{array}$ & $\begin{array}{l}\text { Total number of } \\
\text { patients }\end{array}$ \\
\hline Female & $29(29.2 \%)$ & $48(64 \%)$ & $77(57.5 \%)$ \\
\hline Male & $30(50.8 \%)$ & $27(36 \%)$ & $57(42.5 \%)$ \\
\hline Total & 59 & 75 & 134 \\
\hline
\end{tabular}

Table 2. Patient demographics relative to age group

\begin{tabular}{|l|l|l|l|}
\hline Age group & $\begin{array}{l}\text { Number of patients who } \\
\text { continued treatment }\end{array}$ & $\begin{array}{l}\text { Number of patients } \\
\text { lost to follow-up }\end{array}$ & $\begin{array}{l}\text { Total number of } \\
\text { patients }\end{array}$ \\
\hline $31-40$ & 2 & 9 & 11 \\
\hline $41-50$ & 4 & 12 & 16 \\
\hline $51-60$ & 15 & 22 & 37 \\
\hline $61-70$ & 23 & 23 & 46 \\
\hline $71-80$ & 15 & 9 & 24 \\
\hline Total & 59 & 75 & 134 \\
\hline
\end{tabular}




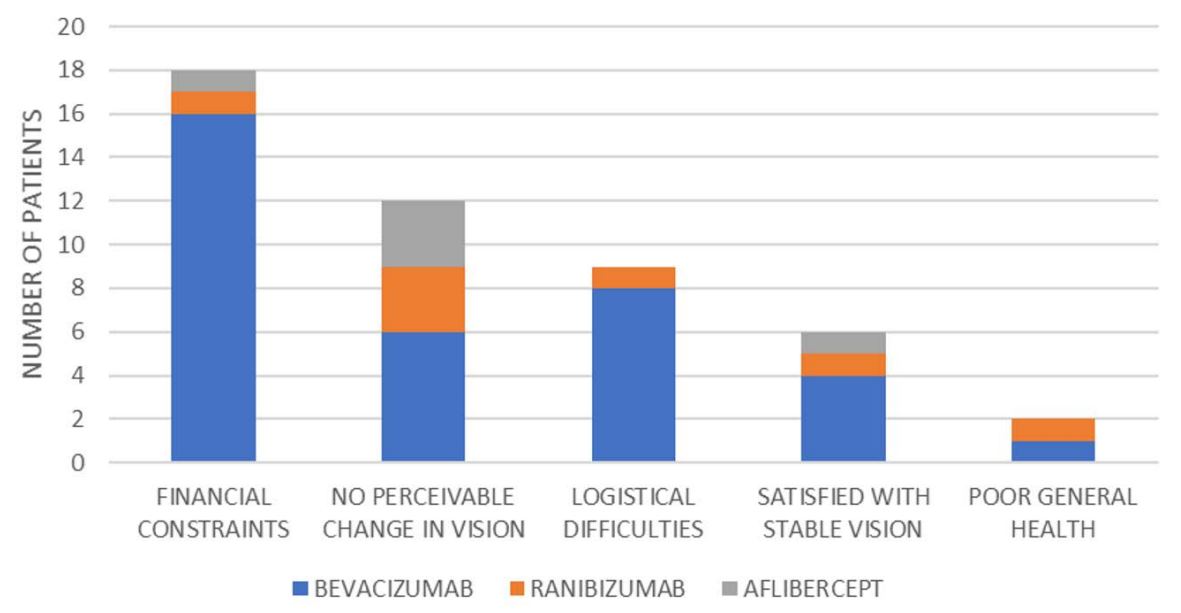

Fig. 2. Reasons for dropout relative to anti-VEGF agents.

Table 3. Number of injections and duration (months) of treatment by group

\begin{tabular}{|l|l|l|}
\hline Reason for dropout & $\begin{array}{l}\text { Number of injections } \\
\text { (mean } \pm \text { SD) }\end{array}$ & $\begin{array}{l}\text { Treatment duration } \\
\text { (mean } \pm \text { SD) }\end{array}$ \\
\hline $\begin{array}{l}\text { Financial } \\
\text { constraints }\end{array}$ & $5.0 \pm 2.8$ & $9.4 \pm 7.3$ \\
\hline $\begin{array}{l}\text { No perceivable } \\
\text { change in vision }\end{array}$ & $6.9 \pm 3.6$ & $9.9 \pm 7.1$ \\
\hline Logistical difficulties & $2.7 \pm 2.9$ & $7.2 \pm 6.8$ \\
\hline $\begin{array}{l}\text { Satisfied with stable } \\
\text { visual acuity }\end{array}$ & $5.3 \pm 1.6$ & $12.0 \pm 5.9$ \\
\hline Poor general health & $2.5 \pm 0.7$ & $4.0 \pm 2.0$ \\
\hline
\end{tabular}

dropouts, is illustrated in Figure 1. Every patient was treatment naïve. The overall mean duration of treatment was 9.9 months (SD 7.1).

Financial constraint was the most common reason for not continuing with treatment. The average number of injections before dropout is shown in Table 3 and the differences between groups were statistically significant $(p=0.0262)$.

The overall percentages of dropouts relative to drug types were $74.5 \%(35 / 47)$ for bevacizumab, $14.9 \%$ (7/47) for ranibizumab, and 10.6\% (5/47) for aflibercept. Figure 2 illustrates the reasons for dropping relative to anti-VEGF agent. These differences were statistically significant $(p=0.0275)$. This was determined based on the medication that the patient had received at the last visit.

The finding that stands out is that among those who cited financial constraints as their reason for withdrawing from the course of treatment, $88.9 \%(16 / 18)$ were 
Table 4. Visual acuity (EDTRS) change by group

\begin{tabular}{|l|l|l|l|l|}
\hline Reason for drop-out & Baseline VA & Final VA & $\begin{array}{l}\text { Change in } \\
\text { VA }\end{array}$ & $\boldsymbol{p}$-Value \\
\hline Financial constraints & $26.69 \pm 26.77$ & $38.65 \pm 29.68$ & $11.96 \pm 14.51$ & 0.0086 \\
\hline $\begin{array}{l}\text { No perceivable change } \\
\text { in vision }\end{array}$ & $35.38 \pm 24.89$ & $38.63 \pm 21.72$ & $2.63 \pm 13.91$ & 0.3484 \\
\hline Logistical difficulties & $32.27 \pm 32.74$ & $27.5 \pm 34.03$ & $\begin{array}{l}-11.00 \pm \\
14.32\end{array}$ & 0.3067 \\
\hline Satisfied with stable VA & $60.00 \pm 25.90$ & $74.44 \pm 7.68$ & $14.44 \pm 27.23$ & 0.0642 \\
\hline Poor general health & $60.00 \pm 7.07$ & $62.50 \pm 3.54$ & $2.50 \pm 3.54$ & 0.3492 \\
\hline
\end{tabular}

on bevacizumab. The mean number of injections before dropout was 6.2 injections. The remaining two patients on aflibercept and ranibizumab had received three injections each. The majority (15 patients) were self-funded, whilst the rest had medical insurance cover. Also of note, two patients were switched from ranibizumab to bevacizumab for financial reasons. In addition, one patient whose vision did not improve with bevacizumab was switched to aflibercept.

\section{Discussion}

In this study, just over a third of patients on anti-VEGF regimens for DMO did not sustain treatment as advised. This is higher than previously reported rates ranging from $15-25 \%$ in studies conducted in Cairo, Paris, Munich, and Pennsylvania. ${ }^{11-14}$

Several reasons could account for this higher-than-expected number. In Malaysia's dual-tier healthcare system, private specialist centers such as SSEC are not funded by the government. Medical expenses are largely covered by private medical insurers or out-of-pocket spending. ${ }^{16}$ It is therefore no surprise that the reason for a third of patients giving up on treatment was financial. Where there is outof-pocket expense, high drug cost is associated with lower treatment compliance. ${ }^{17-}$ ${ }^{19}$ Furthermore, 16 of 18 of these patients were on bevacizumab, which is the most affordable anti-VEGF agent available. It is likely that those in lower socioeconomic brackets opted for bevacizumab and found it difficult to maintain therapy even at the reduced price point. In order to encourage such patients to persevere, the cost of bevacizumab would have to be lowered even further. This is especially needful since, as a group, there was significant improvement in vision.

One-quarter of patients assumed that anti-VEGF therapy had failed due to a lack of visual acuity improvement. They arrived at this conclusion after an average of 6.9 injections and did not consider it worthwhile to persevere. On the other hand, over a tenth were satisfied with their visual gains and thought that subsequent review or treatment was no longer necessary. This may reflect the general popu- 
lation's understanding of DMO and its management. The former should be aware that, in the absence of other factors such as macular ischemia, functional and anatomical improvement may take more time. The latter need to understand that maximum benefit may have not been achieved and there is a possibility of regression if not adequately treated. More effective patient education might lead to improved motivation to continue with treatment. It is therefore important to note that compliance and awareness of DMO management is associated with the patient's views and behavior towards the management of diabetes. ${ }^{20}$ This is where more rigorous clinical counselling including the distribution in up-to-date patient information on various media platforms may prove helpful. Perhaps another approach towards improving compliance in DMO patients would be to encourage multidisciplinary collaboration between ophthalmologists and other healthcare professionals involved in the care of diabetic patients. ${ }^{21}$ Adequately trained retinal counsellors made up of nurses, optometrists, and other paramedical professionals could lend ongoing support to patients along their treatment journey.

Being an ambulatory ophthalmology center that receives many out-of-state patients, it is expected that among those who reported logistical difficulties, 10 out of 12 live between 40 and $190 \mathrm{~km}$ away. Longer-acting agents such as steroid implants should alleviate the burden of frequent visits if there are no contraindications. ${ }^{22-23}$ Shared care between retinal specialists and local general ophthalmologists may also be considered. It is of concern that this group had lost vision during the course of therapy. Although not statistically significant, it does raise the point that easier accessibility to treatment should be considered in any effort to improve outcomes.

To date, this is the only known study analyzing reasons for non-compliance with anti-VEGF therapy among patients with DMO in a private health care setting in Malaysia. The information gained should be helpful in formulating strategies for assisting individuals with DMO to persevere with therapy.

There are a few limitations to this study. First, this is a single-center study covering the southern region of Malaysia and the results may not be representative of the whole nation. Second, $15 \%$ of patients were not contactable because telephone numbers held on the electronic medical records were invalid. However, an $85 \%$ response rate was considered by the authors to be sufficient for useful conclusions to be drawn.

Malaysia comprises people from a wide range of cultural and socioeconomic backgrounds. For future study, it would be important to note how such factors are associated with treatment compliance. Optimal ophthalmic care is vital as part of the ongoing effort to reduce morbidity among the diabetic population of Malaysia. 


\section{Declarations}

\section{Ethics approval and consent to participate}

International Specialist Eye Centre Institutional Review Board approval for the study was granted by the International Specialist Eye Centre (Reference No: 1/2020). Informed consent was provided by the patients at the start of the telephone interview.

\section{Consent for publication}

Not required.

\section{Competing interests}

None.

\section{Funding}

None.

\section{Acknowledgements}

We would like to acknowledge Dr. Robert Yeo Kim Chuan and Dr. Liu Han Seng, who cared for some of the study patients, and staff nurse Angeline Goh Xue Ning for conducting the telephone interviews.

\section{References}

1. Lightman S, Hamish MA. Diabetic Retinopathy. Clin Cornerstone. 2003;5(2):12-21.

2. Yau JW, Rogers SL, Kawasaki R, et al. Global prevalence and major risk factors of diabetic retinopathy. Diabetes Care. 2012;35(3):556-564.

3. Lee R, Wong TY, Sabanayagam C. Epidemiology of diabetic retinopathy, diabetic macular edema and related vision loss. Eye (Lond). 2015;2:17.

4. Wong TY, Sabanayagam C. Strategies to Tackle the Global Burden of Diabetic Reinopathy: From Epidemiology to Artificial Intelligence. Ophthalmologica. 2020;243:9-20. https://www. doi/10.1159/000502387

5. Ramachandran A, Ma RC, Snehalatha C. Diabetes in Asia. Lancet. 2010;375(9712):408-418.

6. Lin S, Ramulu P, Lamoureux EL, et al. Addressing risk factors, screening, and preventative treatment for diabetic retinopathy in developing countries: a review. Clin Exp Ophthalmol. 2016;44:300-320. https://www.doi/10.1111/ceo.12745

7. Institute for Public Health: Ministry of Health Malaysia. National Health and Morbidity Survey. 2019. Available from: http://www.iku.gov.my/images/IKU/Document/REPORT/NHMS2019/Report_ NHMS2019-NCD_v2.pdf. Date accessed: November 23, 2020. 
8. Goh PP, Hussein E, Ismail M. The First Annual Report of the National Eye Database. 2008. Available from: https://www.crc.gov.my/wp-content/uploads/documents/report/1stnedReport.pdf Date accessed: November 23, 2020.

9. Chew FLM, Salowi MA, Mustari Z, et al. Estimates of visual impairment and its causes from the National Eye Survey in Malaysia (NESII). PLoS One. 2018; 13(6): e0198799. https://www.doi/10.1371/ journal.pone.0198799

10. Virgili G, Parravano M, Evans JR, Gordon I, Lucenteforte E. Anti-vascular endothelial growth factor for diabetic macular oedema: a network meta-analysis. Cochrane Database Syst Rev. 2018;10(10):CD007419.

11. Best A, Fajnkuchen F, Nghiem-Buffet S, et al. Treatment Efficacy and Compliance in Patients with Diabetic Macular Edema Treated with Ranibizumab in a Real-Life Setting. J Ophthalmol. 2018; 4610129.

12. Weiss M, Sim DA, Herold T, et al. Compliance and adherence of patients with diabetic macular edema to intravitreal anti-vascular endothelial growth factor therapy in daily practice. Retina. 2018; 38(12):2293-2300.

13. Habib AE, Abdel-Kader AA, Eissa IM, Awadein A. Adherence to Intravitreal Anti-Vascular Endothelial Growth Factor (Anti-VEGF) Drugs in Diabetic Macular Edema in an Egyptian Population: A Health Belief Model. Curr Eye Res. 2018;44(3):303-310.

14. Gao X, Obeid A, Aderman CM, Talcott KE, Ali FS, Adam MK. Loss to Follow-up After Intravitreal AntiVascular Endothelial Growth Factor Injections in Patients with Diabetic Macular Edema. Ophthalmol Retina. 2019;3(3):230-236.

15. Hazem Abdelmotaal, Walid Ibrahim, Mohamed Sharaf, Khaled Abdelazeem, "Causes and Clinical Impact of Loss to Follow-Up in Patients with Proliferative Diabetic Retinopathy", Journal of Ophthalmology, vol. 2020, Article ID 7691724, 8 pages, 2020.

16. The Malaysian Health Care System: A Review. July 2014. Available from: https://www.researchgate. net/publication/237409933_The_Malaysian_Health_Care_System_A_Review. Accessed May 8, 2020.

17. Viswanathan $\mathrm{M}$, Golin CE, Jones CD, et al. Interventions to improve adherence to self-administered medications for chronic diseases in the United States: A systematic review. Ann Intern Med. 2012;157(11):785-795.

18. Eaddy MT, Cook CL, O'Day K, Burch SP, Cantrell CR. How patient cost-sharing trends affect adherence and outcomes: A literature review. P T. 2012;37(1):45-55.

19. Iuga AO, McGuire MJ. Adherence and health care costs. Risk Manag Healthc Policy. 2014;7:35-44. https://www.doi/10.2147/RMHP.S19801

20. Gale R, Scanlon PH, Evans M, et al. Action on diabetic macular oedema: achieving optimal patient management in treating visual impairment due to diabetic eye disease. Eye (Lond). 2017;31(S1):S1-S20.

21. Strain WD, $\operatorname{Cos} X$, Prunte $C$. Considerations for management of patients with diabetic macular edema: Optimizing treatment outcomes and minimizing safety concerns through interdisciplinary collaboration. Diabetes Res Clin Practice. 2017;126:1-9.

22. Mehta H, Gillies M, Fraser-Bell S. Perspective on the role of Ozurdex (dexamethasone intravitreal implant) in the management of diabetic macular oedema. Ther Advc Chronic Dis. 2015;6(5):234-245. https://www.doi/10.1177/2040622315590319

23. Weinberg $\mathrm{T}$, Loewenstein $\mathrm{A}$. The role of steroids in treating diabetic macular oedema in the era of anti-VEGF. Eye. 2020;34:1003-1005. https://doi.org/10.1038/s41433-019-0739-x 